\title{
Strategi Pengembangan Desa Sayan Ubud, Kabupaten Gianyar, Bali, Sebagai Desa Wisata Berbasis Wisata Alam Bija
}

Alinda Thalia a, 1, Saptono Nugroho a, 2

1 alindathalia0902@gmail.com, 2 saptono_nugroho@unud.ac.id

a Program Studi Sarjana Destinasi Pariwisata, Fakultas Pariwisata, Universitas Udayana, Jl. Dr. R. Goris, Denpasar, Bali 80232 Indonesia

\section{Abstract}

Sayan Village is one of the villages in Ubud that has a lot of potential to be used as a tourism village. The first three great potentials are natural tourism, potential opportunities for water tubing tourism, and also the potential of Puri Sayan as a heritage tourism object in Sayan Village, which is being planned by the village government and local communities. In addition to the three great potentials, Sayan Village also has the potential for water tourism with beji spring sources which are a source of water that is purified by the local community and is usually used for melukat. In this case, the researcher focused more on discussing the development of biology natural tourism which is currently used as the center of tourism village activities in Sayan Village.

This study uses collection techniques in the form of observation, interviews, and documentation. The data analysis technique used is descriptive qualitative analysis and SWOT analysis. The technique of determining informants used purposive sampling technique.

The results of this study contain the existing conditions of Desa Sayan based on tourism product components, namely attractions, amenities, accessibility, and ancilliary. And the strategy for developing SWOT-based Sayan Tourism Village. So that the strategies obtained produce the best ways to realize one of the missions of Desa Sayan as a sustainable tourism village.

Keyword: Identification of Existing Conditions, SWOT Analysis, Natural Tourism, Sayan Tourism Village.

\section{PENDAHULUAN}

Salah satu desa yang saat ini berpotensi untuk mengembangkan kegiatan pariwisata sebagai desa wisata yaitu Desa Sayan yang berlokasi di Ubud, Kabupaten Gianyar, Bali. Ubud merupakan salah satu kecamatan di Bali yang terkenal di kalangan wisatawan mancanegara maupun lokal, dikarenakan kegiatan pariwisata. Ubud adalah sebuah kecamatan yang dikelilingi oleh tujuh desa, di timur ada Desa Peliatan dan Desa Mas yang terkenal dengan seni dan budaya serta sudah lebih dulu dikenal dengan desa wisata dengan bermacam-macam kesenian, seperti topeng dan juga museum. Di pintu bagian selatan ada Desa Lotunduh. Sebelum memasuki Desa Sayan, jika berangkat dari arah Batu Bulan ke utara, maka akan melewati Desa Singakerta. Desa Sayan ini murni berada di sebelah barat desa wisata di Ubud. Di sebelah utara Desa Sayan, ada Desa Kedewatan yang terkenal dengan payung rafting dan juga nasi ayam Ibu Mangku Kedewatan. Adapula Desa Petulu yang terkenal dengan Burung Kokokan.

Maka dari itu, Desa Sayan memiliki potensi yang luar biasa besar untuk dijadikan desa wisata, yaitu sebagai pintu masuk Ubud sebelah barat, dari arah Negara dan Kabupaten Badung. Potensi wisata adalah segala sesuatu yang terdapat di daerah tujuan wisata dan merupakan daya tarik agar orang-orang mau datang berkunjung ke tempat tersebut (Mariotti dalam
Yoeti, 1996:172). Potensi wisata alam bija yang berada di Desa Sayan, menjadi salah satu kunci pengembangan Desa Sayan sebagai desa wisata.

Desa Sayan sebagai desa yang memiliki salah satu misi yaitu menjadikan Desa Sayan desa wisata, memiliki beberapa potensi yaitu diantaranya ada tiga potensi besar yang sedang dikembangkan dan juga dalam perencanaan. Tiga potensi itu yang pertama adalah wisata alam bija, peluang potensi wisata water tubing, dan juga potensi Puri Sayan sebagai wisata heritage Desa Sayan sedang dalam perencanaan pemerintah dan masyarakat lokal desa. Selain tiga potensi besar itu juga Desa Sayan memiliki potensi wisata tirta dengan sumber mata air beji yang merupakan sebuah sumber mata air yang disucikan oleh masyarakat setempat dan biasanya digunakan untuk melukat, melukat dapat diartikan sebagai pembersihan diri baik secara jasmani dan batiniah yang dilakukan oleh umat Hindu. Dalam hal ini, peneliti lebih memfokuskan untuk membahas mengenai pengembangan wisata alam bija yang saat ini dijadikan sebagai pusat kegiatan desa wisata di Desa Sayan. Hal yang paling mendasar tentang pengembangan wisata alam bija ini merupakan wujud dari terciptanya pemerataan kegiatan pariwisata di Desa Sayan. Maka dari itulah peneliti tertarik untuk melakukan penelitian terkait dengan strategi pengembangan wisata 
alam bija di Desa Sayan, Ubud, Kabupaten Gianyar, Bali.

Melihat penelitian terdahulu yang relevan dengan penelitian yang sekarang yaitu salah satunya jurnal dengan judul "Strategi Pengembangan Potensi Desa Mengesta Sebagai Desa Wisata Berbasis Ekowisata" oleh Ni Nyoman Sri Astuti (2016), tujuan dari penelitian ini yaitu mengidentifikasi potensi yang terkandung di Desa Mengesta, serta bagaimana penerapan strategi pengembangan dari potensi yang dimiliki Desa Mengesta sebagai desa wisata berbasis ekowisata. Perbedaan yang terdapat antara penelitian terdahulu dengan yang sekarang adalah penelitian terdahulu mengembangkan desa wisata berbasis ekowisata, sedangkan penelitiaan yang sekarang, mengembangkan desa wisata berbasis wisata alam bija. Perbedaan lainnya yaitu lokasi penelitian yang diteliti. Adapun kesamaannya yaitu membahas tentang strategi pengembangan potensi desa wisata dengan menggunakan analisis SWOT.

Beberapa teori dan konsep yang digunakan dalam penelitian ini guna menganalisis masalah yang ada, yaitu teori stakeholder (Deegan, 2004) dalam membahas ataupun mengkaji mengenai komposisi dan peran dari stakeholder di Desa Sayan, konsep komponen produk pariwisata (Cooper, 1995: 81) yang dimaksudkan untuk membahas mengenai kondisi eksisting yang terdapat di Desa Sayan, konsep strategi pengembangan pariwisata (Swarbrooke 1996: 99) dalam menelitik strategi seperti apa yang dapat diterapkan di Desa Sayan demi mewujudkan desa wisata secara merata, konsep potensi wisata (Mariotti dalam Yoeti, 1996: 172) membahas mengenai potensi-potensi wisata yang menjadi kunci utama di dalam pengembangan Desa Wisata Sayan, konsep wisata alam (Hector Ceballos-Lascurain: 1987) yaitu basis yang dipakai ataupun diterapkan dalam kegiatan di Desa Wisata Sayan, konsep desa wisata (Inskeep: 1911) dalam mengkaji Desa Sayan mewujudkan menjadi desa wisata, dan juga konsep pembangunan pariwisata berkelanjutan (Sharpley 2000: 2) hal ini berkaitan dengan bagaimana stakeholder mempertahankan keberlanjutan dari Desa Sayan untuk menjadi desa wisata.

\section{METODE PENELITIAN}

Lokasi dari penelitian ini yaitu di wisata alam bija Desa Sayan, Ubud, Kabupaten Gianyar, Provinsi Bali. Desa Sayan ini berada di sebelah barat Ubud. Ubud tepatnya berada di arah utara Denpasar dan Jimbaran. Jarak tempuh antara Bandara International Ngurah Rai dengan Desa Sayan yaitu $38 \mathrm{~km}$, dengan waku kurang lebih 1 jam 5 menit menggunakan kendaraan bermotor. Dalam penelitian ini data kualitatif meliputi data mengenai gambaran umum Desa Sayan, identifikasi komponen 4A (attraction, amenity, accessibility, dan ancilliary), potensi wisata alam bija, dan strategi pengembangan wisata alam bija (kekuatan, kelemahan, ancaman, dan peluang) di Desa Sayan. Data kuantitatif meliputi data luas lahan wisata alam bija di Desa Sayan, jumlah penduduk Desa Sayan.

Data yang diambil ada data primer ialah data utama dan data sekunder ialah data yang berasal dari dokumen. Teknik pengumpulan data yang didapat yaitu melalui proses observasi, wawancara, dan juga dokumentasi. Teknik penentuan informan menggunakan purposive sampling. Informan yang didapat dalam penelitian ini adalah Kepala Desa Sayan, pihak pemerintah Desa Sayan, Sekretaris Desa Sayan, Ketua Karang Taruna, Ibu-ibu PKK pengelola wisata alam bija, serta masyarakat lokal Desa Sayan.

Teknik analisis data yang digunakan dalam penelitian ini adalah analisis deskriptif kualitatif. Data yang dianalisis berupa potensi wisata alam bija yang ada di Desa Sayan. Kemudian data tersebut digunakan untuk membuat strategi pengembangan desa wisata di Desa Sayan berbasis wisata alam bija. Data yang telah dikumpulkan, diolah dan dianalisis secara deskriptif dengan menggunakan alat analisis SWOT yang merupakan analisis kualitatif yang dilaksanakan dengan mengkaji faktor-faktor internal dan eksternal.

Strategi pengembangan potensi desa wisata dapat dilaksanakan berdasarkan hasil analisis SWOT, yaitu:

a. Strategi I (S - 0), memanfaatkan kekuatan S (Strengths) secara maksimal untuk meraih peluang 0 (Opportunities).

b. Strategi II $(\mathrm{S}-\mathrm{T})$, memanfaatkan kekuatan $\mathrm{S}$ (Strengths) secara maksimal untuk mengantisipasi dan menghadapi ancaman $\mathrm{T}$ (Threats). 
c. Strategi III (W - 0), meminimalkan kelemahan W (Weaknesses) untuk meraih peluang 0 (Opportunities).

d. Strategi IV (W - T), meminimalkan kelemahan W (Weaknesses) untuk menghindari secara lebih baik dari ancaman $\mathrm{T}$ (Threats).

\section{III.HASIL DAN PEMBAHASAN}

\section{A. Kondisi Eksisting Berdasarkan Komponen Produk Pariwisata Di Desa Sayan Ubud}

Penelitian kali ini dilaksanakan di Desa Sayan merupakan salah satu desa yang berada di Ubud, Kabupaten Gianyar, Bali. Ubud adalah kecamatan yang berada di Bali dan sudah berkembang sebagai destinasi wisata yang terkenal bagi wisatawan domestik maupun mancanegara. Banyak potensi yang dimiliki Desa Sayan untuk dijadikan desa wisata. Sesuai dengan salah satu misi Desa Sayan, yaitu ingin menjadikan Desa Sayan sebagai desa wisata. Saat ini, Desa Sayan sedang mengembangkan potensi-potensi yang ada sebagai salah satu cara untuk menjadi desa wisata.

Pertama kali berdirinya Desa Sayan karena adanya Kerajaan Mengwi di sebelah barat dan Kerajaan Peliatan Sukawati (Desa Sayan sebagai perbatasan). Desa Sayan ini dulunya kemungkinan dikuasai oleh Kerajaan Mengwi atau Kerajaan Peliatan. Kerajaan Mengwi terkikis, lalu kerajaan Peliatan yang akhirnya membuat cabang di Kerajaan Ubud. Lambat laun, Kerajaan Ubud lebih maju dari Kerajaan Peliatan, karena memiliki raja yang lebih bijaksana dalam memimpin. Akhirnya di daerah ini ditempatkanlah salah satu penerus dari raja itu atau perwakilan dari raja di Ubud untuk memimpin masyarakat Ubud yang berada di Desa Sayan.

Ada dua desa pakraman yang diwilayahi Desa Sayan yaitu Desa Pakraman Sayan dan Desa Pakraman Penestanan. Dalam perjalanannya waktu tempuh yang dibutuhkan untuk menuju Desa Sayan sekitar 1 jam 20 menit (43 km) dari Jimbaran dan 47 menit $(23 \mathrm{~km})$ dari Denpasar dengan menggunakan kendaraan bermotor. Mata pencaharian masyarakat Desa Sayan yaitu petani, pelukis, bidang pariwisata (pemilik hotel, villa, restaurant), wisata rekreasi (ayung jeram, skateboard park), pasar tradisional.

Pariwisata menjadi sub sektor penting bagi masyarakat Desa Sayan, potensi pariwisata Desa Sayan sudah terkenal ke seluruh mancanegara.
Salah satu upaya stakeholder desa dalam kegiatan pariwisata, selain kreativitas seni budaya yang ada, yaitu mengembangkan wisata alam bija di Desa Sayan. Saat ini sudah dibangun paving block dan jalan setapak yang menjadi jalur untuk tracking dan cycling bagi wisatawan yang ingin menikmati pemandangan alam berupa hamparan sawah seluas 42 hektar. Walaupun saat ini hanya masyarakat sekitar desa yang sudah menikmati. Bija atau wija dalam Bahasa Sansekerta disebut gandaksata yang berasal dari kata ganda dan aksata yang artinya biji padi - padian yang utuh serta berbau wangi.

Ada tiga potensi besar di Desa Sayan, yaitu wisata alam bija, peluang potensi wisata water tubing sebagai wisata air, dan juga potensi Puri Sayan sebagai wisata budaya sekaligus akomodasi tempat penginapan bagi wisatawan di Desa Sayan sedang dalam perencanaan pemerintah dan masyarakat lokal desa. Selain tiga potensi besar itu juga Desa Sayan memiliki potensi wisata tirta dengan sumber mata air beji yang merupakan sebuah sumber mata air yang disucikan oleh masyarakat setempat dan biasanya digunakan untuk melukat, melukat dapat diartikan sebagai pembersihan diri baik secara jasmani dan batiniah yang dilakukan oleh umat Hindu. Di Desa Sayan juga sudah mengadakan event yaitu Gowes For Love yang nantinya akan menjadi event tahunan di Desa Sayan. Event Gowes For Love ini berhubungan dengan wisata alam bija yang berada di Desa Sayan, karena event ini, masuk ke dalam rangkaian kegiatan wisata alam bija.

Atraksi yang ditawarkan wisata alam bija di Desa Sayan, yaitu tracking dan cycling. Wisatawan yang menyukai olahraga lari dan juga bersepeda, atau sekedar berjalan kaki dapat mencobanya di wisata alam bija Desa Sayan. Sembari menikmati pemandangan hamparan sawah seluas kurang lebih 42 hektar, para wisatawan juga disuguhi dengan udara yang bebas polusi dan tentunya lingkungan yang masih asri. Dalam hal ini, pihak pengelola Desa Sayan sudah membangun paving block dan juga jalan setapak yang dapat dilalui wisatawan dengan berjalan kaki ataupun menggunakan sepeda. Pembangunan akses jalan ini dilaksanakan pada Bulan November 2018 lalu. Sebagai bentuk dari melanjutkan program POKDARWIS Desa Sayan yang telah terbentuk dan memusatkan kegiatan desa wisata di Alam Bija Sayan. 
Walaupun saat ini hanya masyarakat sekitar desa yang sudah menikmati, namun diharapkan kedepannya wisatawan mancanegara maupun wisatawan lokal dapat menikmati juga. Hamparan sawah bija yang berada di Desa Sayan ini juga tentunya menjadi suguhan mata bagi para wisatawan yang menikmatinya.

Tidak hanya sampai disitu, pihak pengelola desa dan juga dengan bantuan partisipasi masyarakat Desa Sayan membuat event yang menjadi rangkaian atraksi di wisata alam bija. Event ini bertujuan untuk mengenalkan potensi wisata alam bija, maupun potensi SDM serta membangun semangat masyarakat desa dari kalangan muda di Desa Sayan. Pada tahun ini, tepatnya tanggal 16 -17 Februari 2019 diadakan event dua hari dari pagi sampai malam dengan nama Gowes For Love, event dalam rangka memperingati hari valentine. Event ini merupakan wujud inisiatif dari Sekaa Teruna Bina Warga Banjar Mas, Sayan berkolaborasi dengan Junior Chamber Indonesia (JCI) yang memang menjadi wadah bagi anak muda untuk mengembangan potensi kreatifnya.

Rangkaian acaranya yaitu dengan bersepeda melewati rute sejauh $10 \mathrm{~km}$ di areal Desa Sayan, sampai pemberhentian terakhir yaitu di sebuah lapangan di Desa Sayan. Acara diisi dengan kegiatan interaktif seperti gowes, Zumba dance, Yoga ketawa, Talk show, edukasi sampah kepada anak-anak sekolah dasar, mendongeng, dan acara puncak dimeriahkan dengan konser musik. Acara ini tentunya membutuhkan dana yang lumayan besar, maka dari itu, pihak pengelola acara menyewakan tenda bagi para vendor dan tenant. Artis musik yang diundang yaitu band No Stress dan Robi Navikula serta band-band lokal lainnya, di dalam acara ini juga disuguhi berbagai macam makanan lokal oleh food vendor. Bupati Gianyar Made Mahayastra juga ikut dalam salah satu rangkaian acara Gowes For Love, dengan ikut bersepeda bersama ribuan cyclers.

Event Gowes For Love ini adalah aplikasi terhadap ajaran Tri Hita Karana. Yaitu hubungan manusia dengan Tuhan, serta sesama manusia dan juga dengan lingkungan. Sehingga pada bulan kasih sayang ini, pihak pengelola desa mengaplikasikan dengan bersepeda ria sembari menikmati pemandangan alam, tepatnya dalam ajaran Tri Hita Karana bidang Palemahan (hubungan manusia dengan lingkungan). Juga adanya edukasi kepada masyarakat untuk mengurangi pemakaian kemasan plastik.

Dibawah ini merupakan gambar ataupun hasil foto dari penelitian yang dilakukan, pada foto tersebut mejelaskan bahwa sudah adanya kegiatan leisure dalam mengisi waktu luang yang dilakukan oleh masyarakat lokal yaitu jalan sore di area persawahan alam bija.

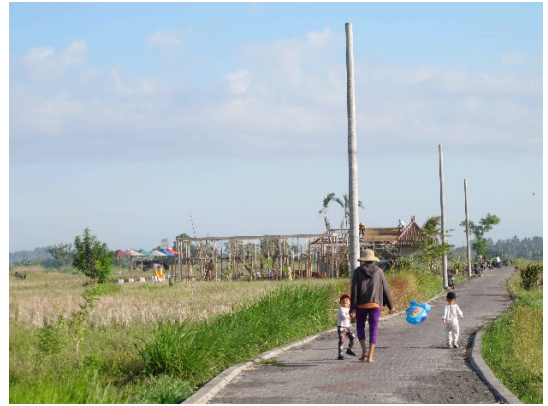

Gambar 1. Masyarakat lokal menikmati jalan sore di wisata alam bija Desa Sayan

Sumber: Hasil Penelitian Lapangan 2019

Memasuki area wisata alam bija, wisatawan dapat menemukan villa di tengah-tengah hamparan sawah alam bija yang dimiliki oleh pihak asing yaitu bernama Jessica. Villa ini dinamakan Villa Spiral. Saat ini, villa pihak asing itu sedang disewa oleh salah satu temannya selama 6 bulan kedepan, akan tetapi dalam proses akan segera dijual. Hal ini dikarenakan pihak asing pemilik villa sudah tinggal dan menetap di negara asalnya yaitu Jerman. Selain villa yang dimiliki pihak asing ini, belum ada tempat penginapan bagi wisatawan di area wisata alam bija yang dikelola oleh masyarakat lokal. Dalam hal ini, sebenarnya masyarakat lokal Desa Sayan dapat menyediakan rumah untuk homestay bagi wisatawan. Penyediaan rumah masyarakat lokal ini dapat di sesuaikan dengan type rumah yang dimiliki oleh masyarakat lokal itu sendiri.

Sedangkan untuk restaurant ataupun tempat makan bagi wisatawan yang berkunjung ke wisata alam bija, salah satu pemilik lahan area persawahan alam bija bekerja sama dengan BUMDes, sedang membangun sebuah rumah makan yang menawarkan masakan daerah dan tentunya dapat menjadi tempat selfie bagi para wisatawan. Ide ini berasal dari bapak pemilik lahan itu sendiri sekaligus mantan pejabat kepala desa. Rumah makan ini merupakan bentuk kerjasama antara Pemerintah Desa dengan pemilik lahan, kemudian BUMDes yang nantinya akan menjalankan usaha rumah makan ini. Pemasukan dari hasil keuntungan rumah 
makan ini akan dengan pemilik lahan sesuai presentase cost of capital.

Tujuannya untuk menunjang atraksi yang ada seperti wisatawan yang melakukan kegiatan tracking, cycling, dan water tubing. Pembangunan ini dimulai pada Bulan April 2019 dan diperkirakan selesai pada Bulan Juni 2019, lahannya sekitar 6 are dengan hiasan kola mikan di dalamnya. Rumah makan ini juga rencananya akan dijadikan tempat pemandian bagi wisatawan setelah melakukan kegiatan wisata water tubbing. Tepatya rumah makan ini berada di bagian tengah-tengah area persawahan alam bija. Kemungkinan besar akan tersedianya lahan parkir di dekat rumah makan bagi kendaraan bermotor wisatawan yang berkunjung ke wisata alam bija.

Pembangunan akses jalan berupa paving block dan juga jalan setapak di area wisata alam bija ini baru dilaksanakan pada Bulan November 2018 lalu, sehingga pihak pengelola belum menambahkan fasilitas tempat sampah di ruasruas jalur tracking dan cycling. Gambar dibawah ini merupakan sedang dalam proses dibangunnya rumah makan di area wisata alam bija yang nantinya berfungsi sebagai tempat makan, istirahat, dan mandi bagi wisatawan.

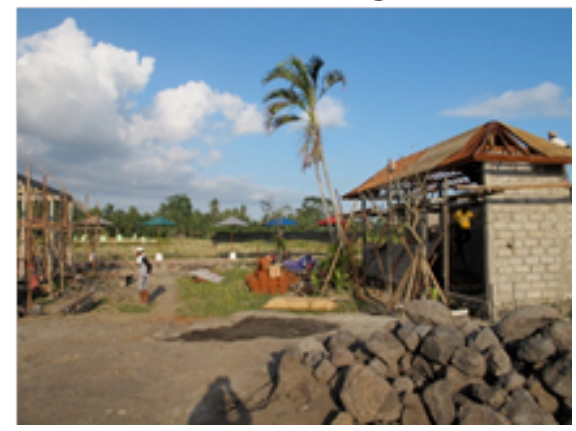

Gambar 2. Pembangunan rumah makan di wisata alam bija Desa Sayan

Sumber: Hasil Penelitian Lapangan 2019

Memasuki area persawahan alam bija memiliki infrastruktur yang sudah dibangun paving block dan juga jalan setapak bagi wisatawan terbilang cukup rapi dan bagus jalanannya. Pembangunan akses jalan ini dilaksanakan pada Bulan November 2018 lalu. Sehingga wisatawan dapat menikmati olahraga tracking dan cycling dengan jalanan yang sudah bagus dan rapi. Wisatawan juga tidak usah khawatir dengan lingkungan sekitar wisata alam bija, karena akses jalan besar maupun jalan kecil yang dilewati untuk menuju Desa Sayan terbilang bersih dan asri. Tidak ada sampah yang berserakan di area wisata alam bija Desa Sayan, walaupun kurangnya persediaan tempat sampah di ruas-ruas area paving block dan jalan setapak wisata alam bija. Dalam hal ini juga kurangnya penanda bahwa sudah memasuki area persawahan alam bija, karena pihak pengelola hanya menancamkan tulisan "wisata alam bija" yang terbuat dari karton di atas area persawahan alam bija. Belum adanya gated atau gerbang yang menandakan bahwa sudah memasuki kawasan wisata alam bija.

Desa Sayan juga memiliki data informasi cukup lengkap yang dapat diakses melalui website yaitu desasayanubud.com, di dalam nya terdapat navigasi berupa profil, sejarah, agenda, aspirasi, visi dan misi, serta potensi yang terdapat di Desa Sayan. Melalui website tersebut juga dapat menghubungi contact yang tertera berupa email, whatsapp, dan juga no telepon pihak pengelola Desa Sayan. Selain itu juga, Desa Sayan memiliki berita kegiatan ter-update desa yang dapat dilihat melalui aplikasi Instagram maupun facebook Desa Sayan Ubud. Gambar dibawah ini merupakan foto yang di upload melalui instagram oleh salah satu stakeholder Desa Sayan pada saat pembangunan paving block.

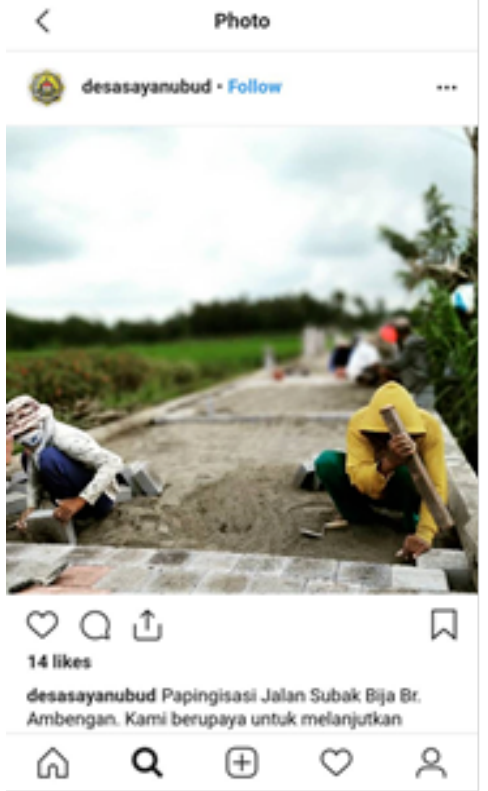

Gambar 3. Pembangunan paving block wisata alam bija Desa Sayan

Sumber: Instagram desa sayan ubud 
Papan penunjuk arah Desa Sayan tersebut kurang terlihat jelas karena tertutupi oleh daun pisang dan peletakan arah penunjuk jalan tersebut sudah cukup lama yaitu tahun 2012 yang dilaksanakan oleh KKN UGM.

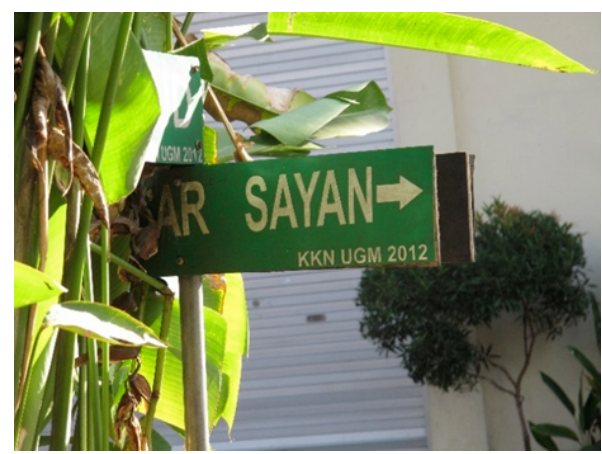

Gambar 4. Arah penunjuk jalan menuju Desa Sayan Sumber: Hasil Penelitian Lapangan 2019

Gambar selanjutan yaitu tanda tulisan "Wisata Alam Bija" yang masih di bentuk dari bahan karton.

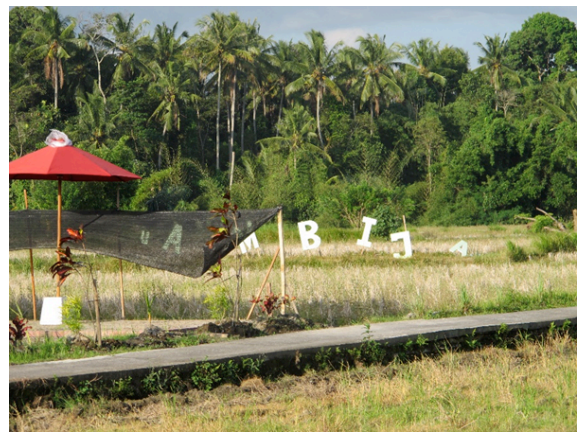

Gambar 5. Tulisan "wisata alam bija" yang terbuat dari karton

Sumber: Hasil Penelitian Lapangan 2019

Komposisi stakeholder di Desa Sayan terbagi dalam tiga kelompok, yaitu pemerintah desa, pengusaha pariwisata, dan masyarakat lokal. Dalam pemerintah desa terdiri dari: Desa Dinas Sayan, Dinas Pariwisata, Dinas Kesehatan, Dinas Pemberdayaan Perempuan Perlindungan Anak Pengendalian Penduduk dan Keluarga Berencana, Badan Narkotika Nasional Kabupaten Gianyar (BNNK), BUMN (PDAM), BUMDes Asta Dana Gantari, TNI/Polri, Badan Permusyawaratan Desa, Lembaga Pemberdayaan Masyarakat, dan Badan Keswadayaan Masyarakat.

Kedua yaitu pengusaha pariwisata terdiri dari: Koperasi Serba Usaha Desa Sayan (internal), Koperasi perBanjar (internal), Yayasan Krysta Guna (eksternal), dan pemilik lahan persawahan alam bija (internal dan eksternal), pemilik akomodasi seperti hotel dan villa di Desa Sayan (eksternal). Ketiga yaitu masyarakat lokal yang terdiri dari native, Karang Taruna Yowana Dharma Kanthi, POKDARWIS, Pers (Bali express, POSBALI, Detik.com, Jarrakpos), Linmas, Posyandu Kumara Santi, Poskamling, Ibu-Ibu PKK, Sekaa Truna-Truni perBanjar, pemilik lahan persawahan alam bija (penduduk Desa Sayan), Lembaga Pengkreditan Desa (Desa Adat Penestanan dan Desa Adat Sayan), mahasiswa Udayana dan UGM yang meneliti Desa Sayan, Kelompok Dasawisma Kamboja, POKDARWIS, kelompok Subak (Bija Ambengan dan Bija Sindu). Masing-masing dari stakeholder yang terdapat di Desa Sayan memiliki status dan peran yang berbeda-beda. Ada beberapa stakeholder yang memang memiliki kerja sama khusus dengan Desa Dinas Sayan, yaitu seperti BNNK Gianyar dan Yayasan Kryasta Guna bekerja sama dalam kegiatan penyuluhan yang memberikan informasi mengenai pentingnya menjaga kesehatan terutama terkait narkoba dan penularan HIV/AIDS. Ketiga dan yang terakhir adalah masyarakat lokal Desa Sayan. Gambar berikut merupakan batu bukti tanda persemian Desa Sayan.

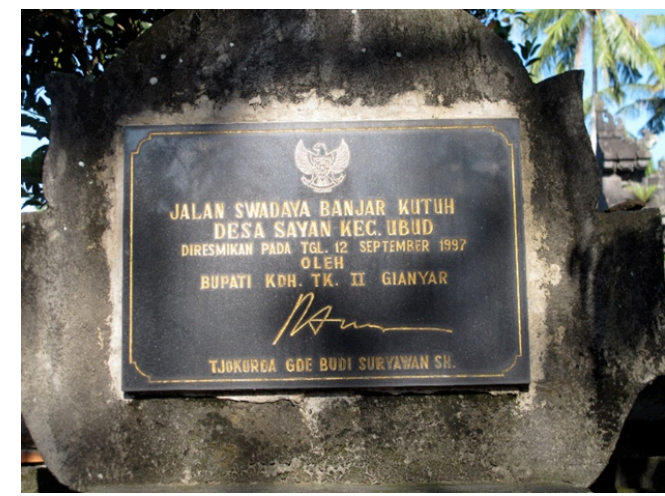

Gambar 7. Tanda peresmian Desa Sayan Sumber: Hasil Penelitian Lapangan 2019

\section{B. Analisis Strategi Pengembangan Desa Wisata Sayan Berbasis Wisata Alam Bija Dalam Matriks SWOT}

1. Analisis Potensi Wisata Dalam SWOT (Strength, Weakness, Opportunity, Threat) berdasarkan komponen produk pariwisata

Analisis potensi wisata Desa Sayan sebagai desa wisata dalam SWOT dapat dijabarkan sebagai berikut: 
a. Strength / Kekuatan yang saat ini dimiliki oleh Desa Sayan adalah (1) Desa Sayan memiliki atraksi dengan ciri khas keunikan yaitu wisata yang memanfaatkan persawahaan alam bija, (2) Event Gowes For Love yang menjadi rangkaian kegiatan wisata alam bija dan akan menjadi event tahunan bertujuan untuk mengenalkan potensi wisata alam bija, (3) Tiga potensi besar sebagai kegiatan pariwisata di Desa Sayan, yaitu wisata alam bija, peluang potensi wisata water tubing sebagai wisata air, dan juga potensi Puri Sayan sebagai wisata budaya dan tempat penginapan di Desa Sayan yang sedang dalam perencanaan, (4) Akomodasi rumah makan memiliki fasilitas untuk pemandian setelah melakukan kegiatan wisata tracking, cycling, dan water tubing, menjadi penopang dalam amenitas, (5) Wilayah Desa Sayan di dominasi dengan pertaniannya yang luas memberikan manfaat besar bagi masyarakat desanya, (6) Akses jalan menuju Desa Sayan yang sudah diaspal dengan bagus dan rapi, (7) Area persawahan alam bija memiliki infrastruktur yang sudah dibangun paving block dan juga jalan setapak bagi wisatawan sebagai jalur tracking dan cycling, (8) Desa Sayan memiliki akses info melalui website, email, whatsapp, instagram, facebook, (9) Anggota kelembagaan desa yang aktif merupakan SDM dikalangan pemuda dan pemudi, (10) Program "Bank Sampah" yang diselenggarakan oleh pemerintah desa dan dijalankan oleh Ibu-Ibu PKK.

b. Weakness / Kelemahan yang saat ini dimiliki oleh Desa Sayan adalah (1) Kurangnya akomodasi berupa tempat penginapan atau homestay bagi wisatawan yang akan bermalam di wisata alam bija, karena hanya ada Villa Spiral di tengah-tengah area persawahan alam bija miliki oleh pihak asing. (investor eksternal), (2) Belum adanya tempat untuk bermalam di wisata alam bija yang dikelola oleh masyarakat lokal, (3) Kurangnya penataan tempat sampah di ruasruas jalan wisata alam bija, (4) Kurangnya arah penunjuk jalan untuk sampai ke wisata alam bija Desa Sayan, (5) Belum adanya gated atau gerbang yang menandakan sudah memasuki kawasan alam bija, (6) Kurang adanya promosi mengenai potensi-potensi yang dimiliki oleh Desa Sayan kepada masyarakat luas, (7) Kurangnya sinergitas kerjasama yang dijalin antara stakeholder yaitu pemerintah desa dengan pemilik lahan persawahan alam bija, (8) Belum adanya pembatasan bagi pengusaha yang ingin membangun Villa ataupun usaha di bidang lainnya pada area persawahan alam bija.

c. Opportunity / Peluang yang saat ini dimiliki oleh Desa Sayan adalah (1) Desa Sayan memiliki peluang untuk dijadikan dan ditetapkan sebagi desa wisata berbasis alam dan budaya, (2) Desa Sayan sebagai desa wisata yang lebih banyak dikenal dan dikunjungi oleh wisatawan mancanegara maupun domestic, (3) Adanya perencanaan dan pengembangan yang baik untuk keberlangsungan Desa Sayan sebagai desa wisata secara berkelanjutan, (4) Partisipasi yang dilakukan oleh masyarakat lokal desa dalam pengembangan kegiatan wisata di Desa Sayan.

d. Threat / Ancaman yang dimiliki oleh Desa Sayan adalah (1) Ancaman kalah daya saing dari luar berupa desa wisata yang sudah lebih berkembang dengan memiliki keunikan yang berbeda, (2) Desa wisata lain yang sudah memiliki SK desa dan dinyatakan sebagai desa wisata secara hukum, (3) Kelengkapan fasilitas ataupun akomodasi yang lebih bagus dimiliki oleh desa wisata lain yang sudah lebih berkembang, (4) Ancaman berupa tidak terealisasikannya Desa Sayan sebagai desa wisata, karena pihak pemilih lahan persawahan alam bija yang tidak mampu bekerjasama secara baik dengan pemerintah desa yang ingin mengembangkan dan mewujudkan desa wisata, (5) Ancaman pencemaran lingkungan berupa semakin banyaknya sampah-sampah akibat dari perkembangan kegiatan wisata di Desa Sayan.

\section{Strategi Pengembangan Desa Wisata Sayan berbasis SWOT (Strategi SO, ST, WO, WT)}

a. Strategi S-O

Strategi Pengembangan Desa Wisata Sayan, meliputi:

1. Pengembangan wisata alam dan budaya di Desa Sayan dengan memanfaatkan keunikan 
atraksi wisata alam bija water tubing, dan Puri Sayan.

2. Memperbanyak event kegiatan di Desa Sayan, guna meningkatkan kunjungan wisatawan dan mengoptimalkan partisipasi masyarakat lokal.

3. Melakukan pengemasan paket wisata tiga potensi besar Desa Sayan sebagai kegiatan pariwisata yang terdiri dari wisata alam bija, water tubing, dan Puri Sayan. Tambahan lainnya yaitu wisata tirta sebagai wisata spiritual.

4. Melakukan pengawasan dan perawatan terhadap pembangunan infrastruktur jalan dan akomodasi rumah makan dengan baik dan terarah agar kegiatan wisata Desa Sayan berkelanjutan.

5. Meningkatkan keaktifan pengurus media sosial dan cetak, agar wisatawan dapat mengetahui upload info terbaru mengenai kegiatan wisata di Desa Sayan.

6. Mengadakan pelatihan-pelatihan kepada masyarakat lokal dalam mengelola Desa Sayan sebagi desa wisata agar dapat berjalan sesuai tujuan secara berkelanjutan.

7. Mempertahankan dan melanjutkan program yang sudah berjalan di masyarakat.

8. Menciptakan brand image Desa Sayan sebagai desa wisata berbasis wisata alam, budaya, dan spiritual.

b. Strategi W-O

Strategi Pengembangan Desa Wisata Sayan, meliputi:

1. Memberikan motivasi kepada masyarakat lokal untuk menyediakan tempat penginapan/homestay bagi wisatawan.

2. Masyarakat lokal Desa Sayan dapat menyediakan rumah untuk homestay bagi wisatawan. Penyediaan rumah masyarakat lokal ini dapat di sesuaikan dengan type rumah yang dimiliki oleh masyarakat lokal itu sendiri.

3. Membangun fasilitas tempat penginapan bagi wisatawan dengan melakukan kerjasama ke berbagai sektor.

4. Menyediakan fasilitas tempat sampah di ruasruas jalan wisata alam bija.

5. Menciptakan dan menjalin kerjasama dengan media-media untuk kegiatan promosi secara baik, agar Desa Sayan lebih dikenal, sehingga meningkatkan kunjungan wisatawan.
6. Melakukan penambahan arah penunjuk jalan dan juga pembuatan gated di kawasan wisata alam bija.

7. Menyelenggarakan kegiatan promosi mengenai Desa Wisata Sayan kepada masyarakat luas.

c. Strategi S-T

Strategi Pengembangan Desa Wisata Sayan, meliputi:

1. Mengembangkan dan mempertahankan keunikan dari potensi-potensi wisata yang ada di Desa Sayan.

2. Menjalin kerjasama yang baik dengan pemerintah daerah dengan tujuan merealisasikan SK Desa Sayan sebagai desa wisata.

3. Mensosialisasikan kepada masyarakat lokal untuk menyediakan tempat akomodasi bagi wisatawan secara baik dan terarah.

4. Mengembangkan dan merawat fasilitas akomodasi yang sudah dibangun di Desa Sayan.

5. Membangun kerjasama yang baik antara pemerintah desa dengan pemilik lahan alam bija serta melakukan musyawarah untuk mengambil keputusan yang menguntungkan kedua belah pihak.

6. Menjalankan program "Bank Sampah Kedarsih" dengan baik dan berkelanjutan.

\section{d. Strategi W-T}

Strategi Pengembangan Desa Wisata Sayan, meliputi:

1. Meningkatkan kesadaran bahwa pariwisata merupakan sebuah sistem yang melibatkan semua komponen (stakeholder) dalam membangun desa wisata di Desa Sayan.

2. Menanamkan pemikiran untuk menjaga lingkungan Desa Sayan kepada masyarakat lokal.

3. Meningkatkan sinergitas kerjasama antara stakeholder Desa Sayan.

\section{IV.SIMPULAN}

Berdasarkan hasil penelitian yang telah dilakukan di Desa Sayan, mengenai Strategi Pengembangan Desa Sayan berbasis wisata alam bija, maka dapat diperoleh kesimpulan bahwa kondisi eksisting suatu desa bertujuan untuk mengidentifikasi kondisi fisik desa, keadaan lingkungan desa, batas-batas desa, dan potensi yang terdapat di desa tersebut. Dalam penelitian 
ini, akan membahas tentang kondisi eksisting Desa Sayan berbasis komponen produk pariwisata yaitu atraksi, aksesibilitas, ancilliary, dan amenity. Atraksi yang ditawarkan wisata alam bija di Desa Sayan, yaitu tracking dan cycling. Event yang diselenggarakan di wisata alam bija adalah Gowes For Love. Tiga potensi besar sebagai kegiatan pariwisata di Desa Sayan, yaitu wisata alam bija, peluang potensi wisata water tubing sebagai wisata air, dan juga potensi Puri Sayan sebagai wisata budaya dan tempat penginapan di Desa Sayan yang sedang dalam perencanaan. Juga potensi lainnya yaitu wisata tirta sebagai wisata spiritual. Amenity ataupun fasilitas sebagai penopang kegiatan pariwisata yang ada di wisata alam bija, yaitu rumah makan yang sedang dalam pembangunan dan dikelola oleh pemilik lahan bekerjasama dengan BUMDes. Tujuannya untuk menunjang atraksi tracking, cycling, dan water tubing. Akses jalan besar menuju Desa Sayan sudah diaspal dengan bagus dan juga tidak begitu sulit untuk menemukan desa tersebut, jika menggunakan aplikasi google maps ataupun aplikasi peta lainnya. Memasuki area persawahan alam bija memiliki infrastruktur yang sudah dibangun paving block dan juga jalan setapak bagi wisatawan. Desa Sayan juga memiliki data informasi cukup lengkap yang dapat diakses melalui website, email, whatsapp, facebook, dan instagram. Ancilliary merupakan pelayanan yang disediakan pada suatu destinasi wisata, pelayanan tersebut dapat berupa pelayanan jasa stakeholder yang dimiliki oleh suatu destinasi wisata. Dalam hal ini, Desa Sayan memiliki SDM yang sudah membangun organisasi di dalamnya baik di desa dinas maupun desa adat. Serta adanya visi dan misi yang sudah disusun oleh pemerintah desa Desa Sayan.

Strategi Pengembangan Desa Sayan sebagai desa wisata berbasis wisata alam bija dapat disimpulkan bahwa pengembang desa wisata lebih ditekankan kepada penciptaan brand image Desa Sayan sebagi desa wisata berbasis wisata alam; budaya; dan spiritual; pengadaan pelatihan-pelatihan kepada stakeholder Desa Sayan secara terarah dalam mengelola desa wisata yang berkelanjutan, melakukan pengemasan terhadap potensi-potensi wisata yang terdapat di Desa Sayan, menyelenggarakan kegiatan promosi mengenai Desa Wisata Sayan kepada masyarakat luas maupun wisatawan, pembangunan dan perbaikan akomodasi dan fasilitas-fasilitas pendukung pariwisata, menciptakan pemeliharaan potensi-potensi yang terdapat di Desa Sayan, menjaga dan merawat fasilitas pendukung pariwisata yang sudah ada, serta peningkatan sinergitas kerjasama antara stakeholder Desa Sayan. Dalam mencapai tujuan bersama yang masuk ke dalam salah satu misi desa yaitu menjadikan Desa Sayan sebagai desa wisata yang berkelanjutan.

Adapun beberapa saran yang didapatkan dari hasil temuan dan penelitian di lapangan yaitu Saran kepada Pemerintah Desa, agar meningkatkan sinergitas kerja sama antara pemerintah desa dengan masyarakat lokal, memberikan pelatihan-pelatihan mengenai pengelolaan desa wisata kepada masyarakat lokal, lebih mengoptimalkan pembangunan fasilitas pendukung pariwisata, menjalin kerjasama yang baik dengan pemerintah daerah demi terwujudnya Desa Sayan sebagai desa wisata. Memberikan brang image pada salah satu misi Desa Sayan yaitu menjadikan Desa Sayan desa wisata berbasis wisata alam, budaya, dan spiritual. Saran kepada pemilik lahan persawahan alam bija dan juga pemerintah desa, agar menciptakan aturan pembatasan bagi pengusaha yang ingin membangun Villa ataupun usaha di bidang lainnya pada area persawahan alam bija dalam memfokuskan wisata alam bija pada kegiatan pariwisata yang menunjang masyarakat lokal. Saran kepada masyarakat lokal agar lebih peduli terhadap pengembangan desa wisata di Desa Sayan, serta ikut berpartisipasi dalam pengembangannya sehingga dalam perkembangannya nanti dapat memberikan manfaat positif bagi kesejahteraan masyarakat lokal.

\section{DAFTAR PUSTAKA}

Rangkuti, Freddy. 2003. Analisis SWOT Teknik Membedah Kasus Bisnis. Jakarta: Penerbit PT Gramedia Pustaka Utama.

Arida, I Nyoman Sukma. 2016. Dinamika Ekowisata Tri Ning Tri di Bali. Bali : Penerbit Pustaka Larasan bekerjasama dengan Fakultas Pariwisata Universitas Udayana.

Sunarta, Nyoman dan I Nyoman Sukma Arida. 2017. Pariwisata Berkelanjutan. Bali : Penerbit Cakra Press ( Anggota IKAPI Bali ) bekerjasama dengan Fakultas Pariwisata Universitas Udayana.

Hornby, Hunziker dan Kraft. 1942. Pengertian Wisata. Jakarta: PT Gramedia. 
Vol. 7 No 2, 2019

Mariotti dalam Yoeti. 1996:172. Pengantar Ilmu Pariwisata. Bandung: Angkasa Offset.

Nurhasanah, Nidya. Analisis SWOT IFAS dan EFAS. Scribd.

Astuti, Ni Nyoman Sri. 2016. Strategi Pengembangan Potensi Desa Mengesta Sebagai Desa Wisata
Berbasis Ekowisata. Politeknik Negeri Bali.

Wiguna, Putu Aditya Dharma Arya. 2018. Strategi Pengembangan Potensi Desa Wisata di Desa Wisata Kerta, Kecamatan Payangan, Kabupaten Gianyar, Bali. Fakultas Pariwisata Universitas Udayana. 